\title{
Design, Fabrication, and Testing of Prototype of Total Lumbar Disc Replacement
}

\author{
Rela Adi Himarosa ${ }^{a}$, Suyitno ${ }^{\text {b }}$ \\ a Universitas Muhammadiyah Yogyakarta \\ Jl. Brawijaya, Tamantirto, Kasihan, Bantul, Daerah Istimewa Yogyakarta, Indonesia \\ +62-274-387655 \\ e-mail: rela.himarosa@umy.ac.id \\ ${ }^{\mathrm{b}}$ Gadjah Mada University \\ Jl. Grafika No. 2, Yogyakarta, Indonesia \\ +62-274-521673 \\ e-mail: suyitno@ugm.ac.id
}

\begin{abstract}
Total Disc Replacement (TDR) implant is part of the prosthesis to treat degenerative disease by retaining the maneuverability of the disk itself. The TDR implant allows to repair the movement of the spines, absorbs the friction of intervertebral discs, and restore the height of the vertebrae. In this study, we constructed a new model of TDR implant, which is feasible to be massproduced in Indonesia and performed static test to examine the mechanical properties of the new model. Before starting the prototype production, the finite element simulation is necessary. Simulation using Abaqus 6.14 software show that our design is safe from mechanical failure. The simulation test was performed using the static general model, non linear by considering the plasticity of UHMWPE material. Manufactured using CNC 3 Axis and the prototype was tested with ASTM 2077 standards, using two calibration model on horizontal position and tilted position of $27^{\circ}$ to measure the compressive strength and shear strength respectively. The static experiment of TDR implant showed that the maximum strength of UHMWPE inlay can load 7225 $N$ in compressive test and $7098 N$ in compressive-shear test. Deformation maximum of $0,95 \mathrm{~mm}$ compressive test and $1,8 \mathrm{~mm}$ compressive-shear test.
\end{abstract}

Keywords: implant; prostesis; intervertebral disc; TDR

\section{INTRODUCTION}

Lower back bone pain is a disease commonly affects adults in the United States. According to a national survey conducted by the Centers for Disease Control and Prevention (Center for Disease Control and Prevention / CDC), as much as $28.8 \%$ of adults suffer low back pain (1). Signs of degenerative disk disease have been observed in the age group of 11-16 years old, increase sharply at the age of 50, and got worse at the age of 70 years old (2). The occurrence of lower back bone pain is often associated with hyperextension lumbar lordosis, degenerative disk disease, or other injury to the disc (1).

TDR history begins in 1960 (3),(4) when Fernstrom first lumbar implantation using steel balls, followed by Schellnack and Buttner in 1980, developed TDR implant SB Charité ${ }^{\circledR}$ in Germany and enhanced to new models SB Charité ${ }^{\circledR}$ III Figure 2.1a. Marney also developed Prodisc-L® Figure 2.1b in France in 1989 which is first used in 1990

TDR implants should meet three criteria in order to be an effective implant. Implants should be solid, not damaging the interface and the structure of the spine (vertebral body), and resistant to wear and tear (1). In addition to the above criteria, implant material must be compatible with the body (in vivo) for 40 years (5). One of pre-clinical testing in implant Charité $\circledast$ SB-III and Prodisc $L \circledast$ used static testing compressive and shear. 
The purpose of this study is to obtain the stability of the spine and restore the physiological curvature of the spine.

\section{Methods}

\subsection{Design Implant}

The process of making a prototype human spinal lumbar TDR requires material that has been classified as a biomaterial (6). The material used is $316 \mathrm{~L} \mathrm{SS}$ and polymer ultrahigh molecular weight polyethylene UHMWPE is used as a cushion inlay on the implants (7).

The implant was designed using Autodesk® Inventor® 2015 software in 3D modeling. Geometry data obtained is converted into the form of 3D models to do the next process stage, which is finite element analysis and CNC machining process.

Disc replacement should be designed based on the variation and size pattern (morphometric) of each individual. Gocmen-Mas, et al (2010) studied the anatomical data of 25 healthy people consisted of 13 men and 12 women in the age of 22 to 49 years and evaluate the spine. Table 2.1-2.4 shows the results of the study (8).

Table 2.1 Heigh anterior and heigh central lumbar spine L1-L5 (8).

\begin{tabular}{lccllll}
\hline Spine & $\begin{array}{c}\text { Mvg. Ha } \\
\mathbf{\pm \text { Dev }}\end{array}$ & $\begin{array}{c}\text { Avg. Hc } \\
\mathbf{\pm \text { Dev }}\end{array}$ & $\begin{array}{c}\text { Sig. } \\
\mathbf{P} \text { Ha-Hc }\end{array}$ & $\begin{array}{c}\text { Avg. Ha } \\
\mathbf{\pm D e v}\end{array}$ & $\begin{array}{c}\text { Hc } \\
\text { Mean } \pm \\
\text { Dev }\end{array}$ & $\begin{array}{c}\text { Sig. } \\
\mathbf{P}_{\text {Ha-Hc }}\end{array}$ \\
\hline L1 & $2,29 \pm 0,23$ & $2,28 \pm 0,13$ & ns & $2,42 \pm 0,16$ & $2,29 \pm 0,14$ & ns \\
L2 & $2,45 \pm 0,35$ & $2,36 \pm 0,24$ & ns & $2,57 \pm 0,15$ & $2,38 \pm 0,21$ & ns \\
L3 & $2,51 \pm 0,28$ & $2,35 \pm 0,17$ & $<0.05$ & $2,65 \pm 0,25$ & $2,31 \pm 0,27$ & $<0.001$ \\
L4 & $2,52 \pm 0,18$ & $2,22 \pm 0,12$ & $<0.001$ & $2,69 \pm 0,28$ & $2,25 \pm 0,16$ & $<0.001$ \\
L5 & $2,59 \pm 0,13$ & $2,27 \pm 0,16$ & $<0.001$ & $2,74 \pm 0,24$ & $2,28 \pm 0,19$ & $<0.001$ \\
\hline
\end{tabular}

$\mathrm{Ha}:$ Height anterior

$\mathrm{Hc}$ : Height central

Table 2.2 Transversal diameter (cm) L1-L5 lumbar spine (8).

\begin{tabular}{lccc}
\hline Spine & $\begin{array}{c}\text { Men }(\mathbf{n = 1 3} \\
\text { TD } \\
\text { Avg. } \pm \text { SD }\end{array}$ & $\begin{array}{c}\text { Women }(\mathbf{n = 1 2}) \\
\text { TD } \\
\text { Avg. } \pm \text { SD }\end{array}$ & $\begin{array}{c}\text { Sig } \\
\mathbf{P s e}_{\text {sex }}\end{array}$ \\
\hline L1 & $4,88 \pm 0,37$ & $4,78 \pm 0,54$ & $\mathrm{~ns}$ \\
L2 & $5,23 \pm 0,31$ & $5,21 \pm 0,42$ & $\mathrm{~ns}$ \\
L3 & $5,39 \pm 0,43$ & $5,36 \pm 0,25$ & $\mathrm{~ns}$ \\
L4 & $5,65 \pm 0,25$ & $5,64 \pm 0,36$ & $\mathrm{~ns}$ \\
L5 & $5,73 \pm 0,44$ & $5,72 \pm 0,31$ & $\mathrm{~ns}$ \\
\hline
\end{tabular}

TD : Transversal Diameter

Table 2.3 Anteroposterior diameter (cm) L1-L5 lumbar spine (8).

\begin{tabular}{lccc} 
Spine & $\begin{array}{c}\text { Men }(\mathbf{n = 1 3} \\
\text { APD } \\
\text { Avg. } \pm \text { SD }\end{array}$ & $\begin{array}{c}\text { Women }(\mathbf{n}=12) \\
\text { APD } \\
\text { Avg. } \pm \text { SD }\end{array}$ & $\begin{array}{c}\text { Sig } \\
\text { s sex }\end{array}$ \\
\hline L1 & $3,46 \pm 0,21$ & $3,37 \pm 0,24$ & $\mathrm{~ns}$ \\
L2 & $3,61 \pm 0,30$ & $3,53 \pm 0,27$ & $\mathrm{~ns}$ \\
L3 & $3,72 \pm 0,32$ & $3,61 \pm 0,20$ & $\mathrm{~ns}$ \\
L4 & $3,33 \pm 0,25$ & $3,79 \pm 0,35$ & $\mathrm{~ns}$ \\
L5 & $3,95 \pm 0,34$ & $3,88 \pm 0,18$ & $\mathrm{~ns}$ \\
\hline
\end{tabular}

APD : Anteroposterior diameter 


\begin{tabular}{|c|c|c|c|c|c|}
\hline \multirow{3}{*}{ Spine } & \multicolumn{4}{|c|}{ Table 2.4 Disc height average value L $1-L 5$ (8) } & \multirow{3}{*}{$\begin{array}{c}\text { Sig } \\
\text { P sex }_{\text {Sig. }} \\
\text { Sig } \\
\text { P }_{\text {sex }(\mathrm{DHa})}\end{array}$} \\
\hline & \multicolumn{2}{|c|}{ Men (13) } & \multicolumn{2}{|c|}{ Women (12) } & \\
\hline & $\begin{array}{c}\text { DHa } \\
\text { Avg. } \pm \text { SD }\end{array}$ & $\begin{array}{c}\text { DV } \\
\text { Avg. } \pm \text { SD }\end{array}$ & $\begin{array}{c}\text { DHa } \\
\text { Avg. } \pm \text { SD }\end{array}$ & $\begin{array}{c}\text { DV } \\
\text { Avg. } \pm \text { SD }\end{array}$ & \\
\hline L1-L2 & $0,88 \pm 0,16$ & $17,69 \pm 3,84$ & $0,88 \pm 0,17$ & $15,17 \pm 1,34$ & ns \\
\hline L2-L3 & $0,95 \pm 0,15$ & $20,36 \pm 4,15$ & $0,98 \pm 0,13$ & $16,23 \pm 1,27$ & ns \\
\hline L3-L4 & $1,10 \pm 0,21$ & $21,58 \pm 4,07$ & $1,08 \pm 0,18$ & $18,40 \pm 1,89$ & ns \\
\hline L4-L5 & $1,16 \pm 0,43$ & $22,16 \pm 3,85$ & $1,20 \pm 0,33$ & $19,28 \pm 2,12$ & ns \\
\hline
\end{tabular}

DV : Disc Volume

Figure 2.1 shows the images of CAD models and product prototypes. The model of TDR implant consists of three parts, the upper end plate, bearing inlay, and the lower endplate. The upper and lower endplate are made from 316L SS while bearing inlay is made from UHMWPE.

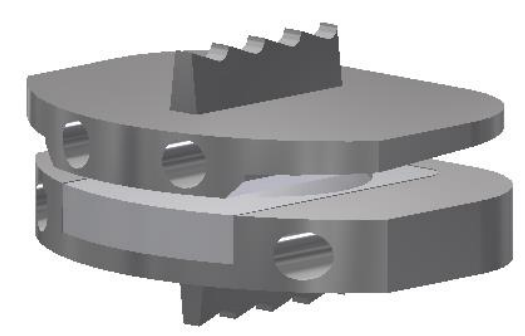

(a)

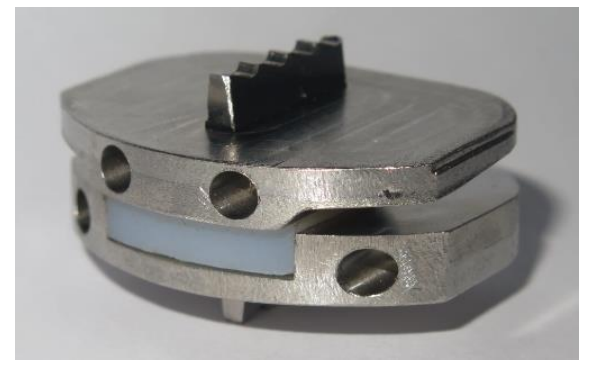

(b)

Figure 2.1 a) Model CAD implan TDR, b) TDR implant prototype manufacturing using CNC

\subsection{Testing Prototype and Loading Condition}

Spine receives the load from a combination of weight, muscle activity, ligament pull, and external force. Posture affects the loading of the spine. The spine is more depressed by the muscles in standing condition. Center of gravity is generally in front of the lumbar spine (9). The amount of load that occurs in each posture position is shown in Table 2.5. Static test performed refers to 2077 ASTM Test Methods For Intervertebral Body Fusion Devices Figure 2.2 (10).

Table 2.5 Amount of load in each posture position (9).

\begin{tabular}{|c|c|}
\hline Activity & Load on L3 disc (N) \\
\hline Supine, awake & 250 \\
\hline Supine, traction & 0 \\
\hline Supine, arm exercise & 500 \\
\hline Upright sitting without support & 700 \\
\hline Sitting with lumbar support, $110^{\circ}$ incline & 400 \\
\hline Standing at ease & 500 \\
\hline Coughing & 600 \\
\hline Forward bend $20^{\circ}$ & 600 \\
\hline Forward bend $40^{\circ}$ & 1000 \\
\hline Forward bend $20^{\circ}$ with $20 \mathrm{~kg}$ & 1200 \\
\hline Forward bend $20^{\circ}$ and rotated $20^{\circ}$ with $10 \mathrm{~kg}$ & 2100 \\
\hline Sit up exercises & 1200 \\
\hline Lifting $10 \mathrm{~kg}$, back straight, knees bent & 1700 \\
\hline Lifting $10 \mathrm{~kg}$, back bent & 1900 \\
\hline Holding $5 \mathrm{~kg}$, arms extended & 1900 \\
\hline
\end{tabular}

JEMMME | Journal of Energy, Mechanical, Material, and Manufacturing Engineering 


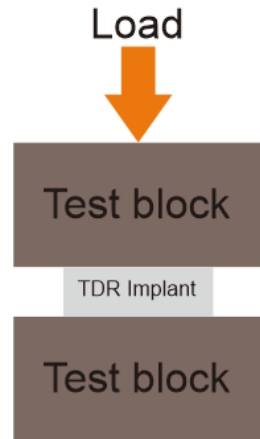

(a)

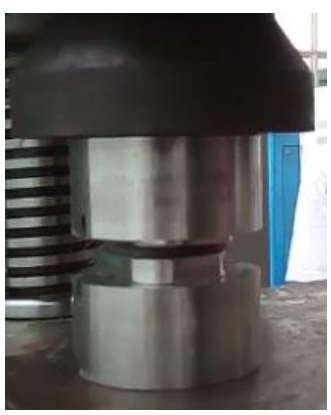

(c)

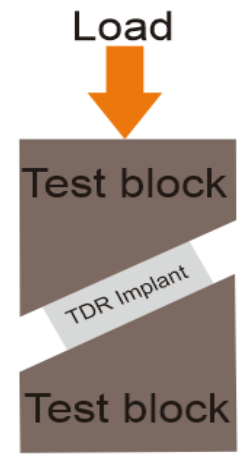

(b)

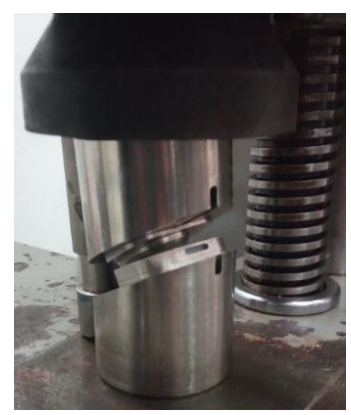

(d)

Figure 2.1 TDR implant test scheme a), c) Compressive test setup; b),d) Compressive shear test setup

\section{Result ANd Discussion}

The TDR prototype requires a high degree of precision and accuracy. Machine CNC three axes are used in machining processes that can be produced in Indonesia. Suitable implant design fitted to the vertebrae shown in the Figure 3.1.
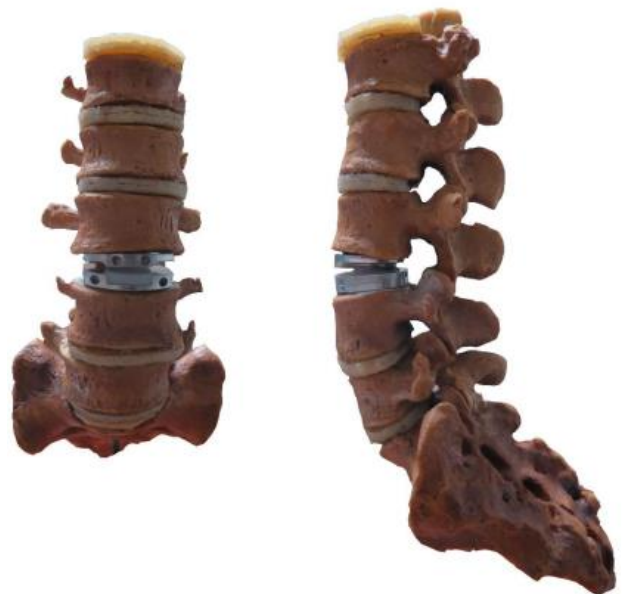

Figure 3.1 TDR prototype in the vertebrae

The testing process of implants TDR showed the capability of bearing the weightbearing UHMWPE inlay. The results obtained in static testing graph show the relationship between force and displacement. In the compressive strength test show obtained values at a maximum of $7225 \mathrm{~N}$ with a displacement of $0.95 \mathrm{~mm}$ while for the compressive shear test the maximum value is $7098 \mathrm{~N}$ with a displacement of $1.8 \mathrm{~mm}$. The results are shown in Graphic 3.1. 


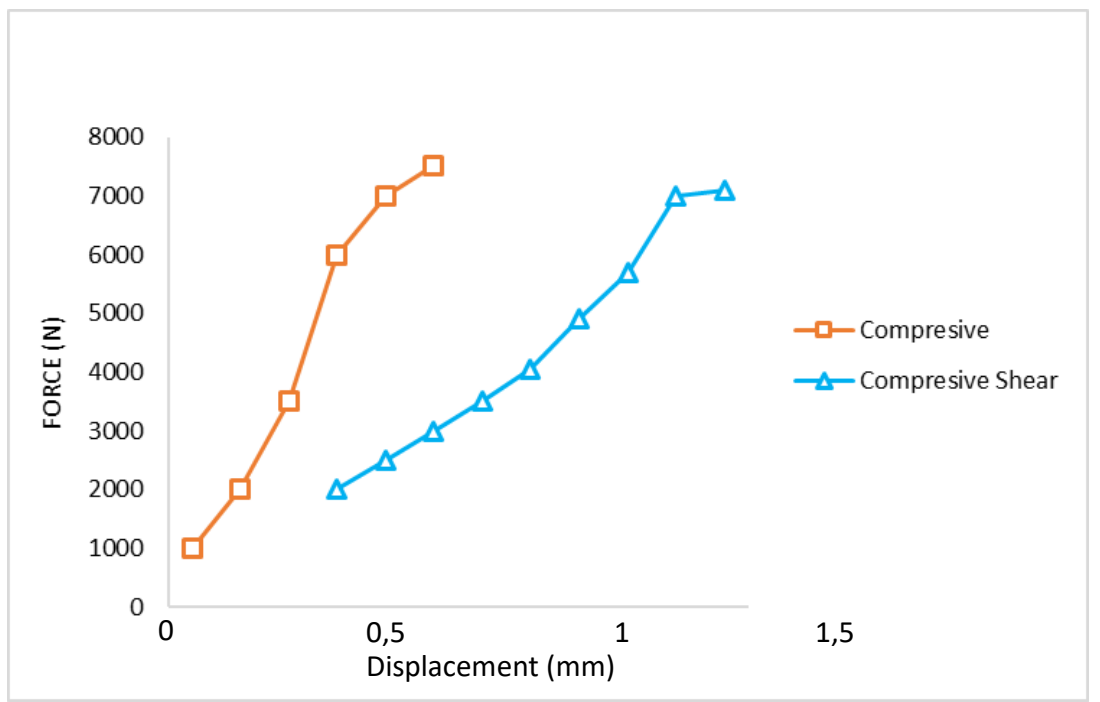

Graphic 3.1 Relations force displacement

The weight-loading on the implant will damage the UHMWPE inlay, which is visible from the direct observation on the shape of the UHMWPE inlay (Figure 3.2). The damage causes reduce of inlay ability to withstand loads showed by the changes of the inlay form which is worse when loading is performed when inlay reach the maximum load (Figure 3.3). After experiencing the maximum imposition, inlay ability to withstand the load will be reduced, as shown when UHMWPE inlay was pressed, it only holds $5018 \mathrm{~N}$ and $3818 \mathrm{~N}$ of compressive shear.

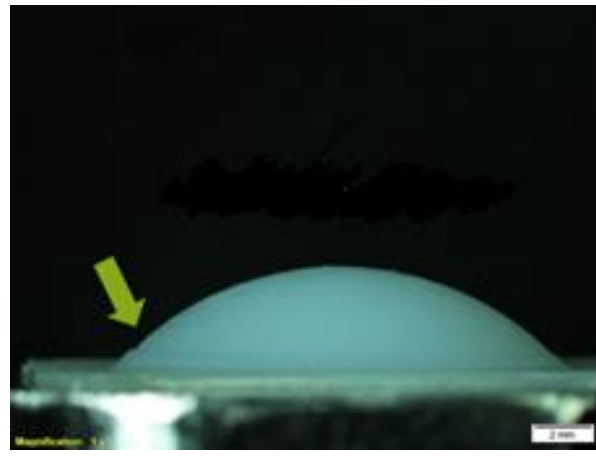

a

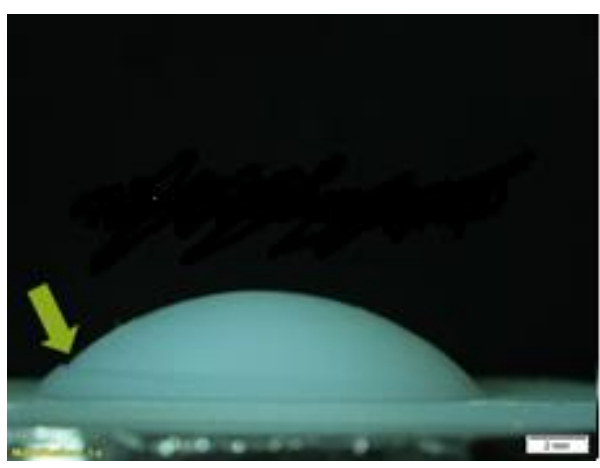

b

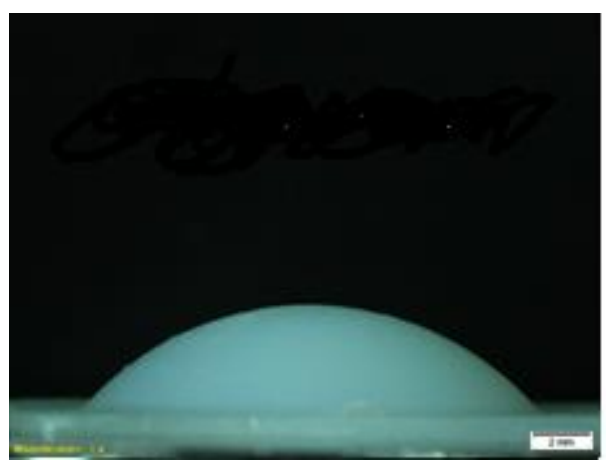

C

Figure 3.2 Deformation of UHMWPE inlay until maximum load a) compressive strength, b) compressive shear, c) normal inlay (deformation shown by green arrows) 


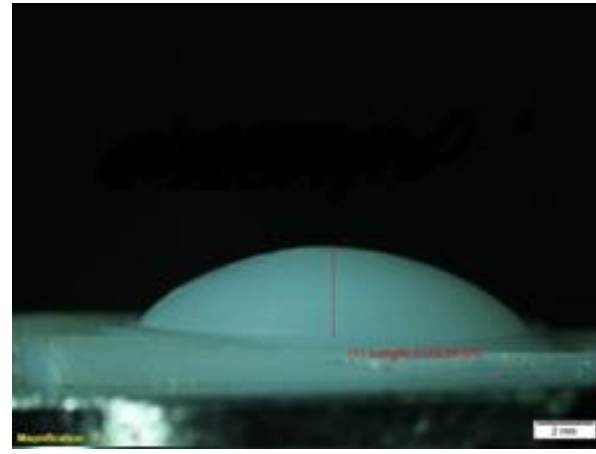

a

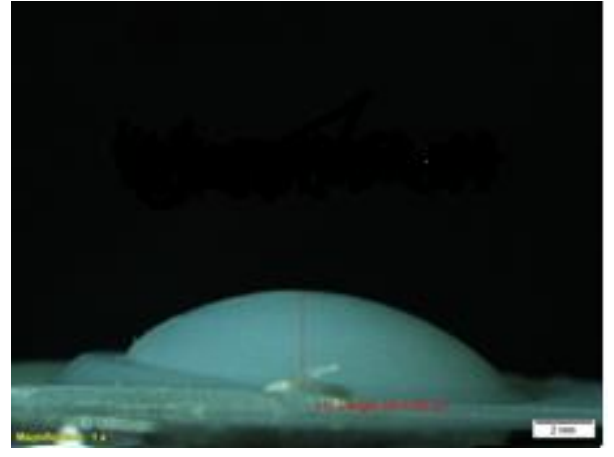

b

Figure 3.3 Deformation of loading up a) compressive strength, b) compressive shear

\section{Conclusion}

The static test results showed that maximum strength of the implant bearings UHMWPE inlay, a force of $7225 \mathrm{~N}$ on the compressive strength test and compressive shear test of 7098 is eligible as a reference for further clinical testing. The loads on the spine ranges from 250-1900 N (9) means that the strength of the new model inlay's safety factor is 3.7-3.8. The design is suitable as lumbar total disc replacement implant.

\section{ACKNOWLEDGMENTS}

This research is funded by PUPT Gadjah Mada University.

\section{REFERENCES}

1. Reeks J, Liang $H$. Materials and Their Failure Mechanisms in Total Disc Replacement. Lubricants [Internet]. 2015;3(2):346-64. Available from: http://www.mdpi.com/2075-4442/3/2/346/

2. Raj PP. Intervertebral Disc: Anatoomy Physiology Pathophysiology Treatment. Pain Pract. 2008;8:18-44.

3. Khoo LT, Geisler FH, Abitbol JJ. Lumbar disc replacement. Minim Invasive Proced Spine Surg. 2007;(1):245-59.

4. Vital JM, Boissière L. Total disc replacement. Orthop Traumatol Surg Res [Internet]. Elsevier Masson SAS; 2014;100(1 $\quad$ S):S1-14. Available from: http://dx.doi.org/10.1016/j.otsr.2013.06.018

5. Mayer HM. Total lumbar disc replacement. J Bone Jt Surg - Br Vol [Internet]. 2005;87-B(8):1029-37. Available from: http://www.bjj.boneandjoint.org.uk/cgi/doi/10.1302/0301-620X.87B8.16151

6. Oldani C, Dominguez A. Titanium as a Biomaterial for Implants. Recent Adv Arthroplast [Internet]. 2012; Available from: http://www.intechopen.com/books/recent-advances-in-arthroplasty/titanium-as-abiomaterial-for-implants

7. Patel N, Gohil P. A review on biomaterials: scope, applications \& human anatomy significance. Int J Emerg Technol Adv Eng. 2012;2(4):91-101.

8. Gocmen-Mas N, Karabekir H, Ertekin T, Edizer M, Canan Y, Duyar I. Evaluation of Lumbar Vertebral Body and Disc: A Stereological Morphometric Study. Int J Morphol [Internet]. 2010;28(3):841-7.

Available from: http://www.scielo.cl/pdf/ijmorphol/v28n3/art28.pdf

9. Ferguson S. Biomechanics of the spine. Spinal Disord Fundam Diagnosis Treat. 2008;107(3):41-66.

10. Schmoelz W, Kienle A. Manual of Spine Surgery. 2012;23-6. Available from: http://link.springer.com/10.1007/978-3-642-22682-3 